\title{
Service Products and Productization
}

\author{
Jochen Wirtz, Martin P. Fritze, Elina Jaakkola, \\ Katja Gelbrich, and Nicole Hartley ${ }^{1}$
}

Accepted for Publication in Journal of Business Research

August 16, 2021

\begin{abstract}
Suggested Citation: Wirtz, Jochen, Martin P. Fritze, Elina Jaakkola, Katja Gelbrich, and Nicole Hartley (2021), "Service Products and Productization," Journal of Business Research, forthcoming
\end{abstract}

\footnotetext{
${ }^{1}$ Jochen Wirtz, Vice Dean MBA Programmes and Professor of Marketing at NUS Business School, National University of Singapore, Singapore. Jochen is the corresponding author and can be reached at jochen@nus.edu.sg. Martin P. Fritze, Assistant Professor of Trade Fair Management and Marketing (endowed by KoelnmesseStiftung) at University of Cologne, Germany, email: fritze@wiso.uni-koeln.de.

Elina Jaakkola, Professor of Marketing, Turku School of Economics, University of Turku, Finland, elina.jaakkola@utu.fi.

Katja Gelbrich, Professor and Head of Department of International Management, Catholic University Eichstaett-Ingolstadt, Germany, katja.gelbrich@ku.de

Nicole Hartley, Professor of Marketing at the UQ Business School, University of Queensland, Australia, n.hartley@business.uq.edu.au.

The authors gratefully acknowledge the valuable input and feedback provided by Lydia Hanks (J. Willard Marriott, Sr. Professor in Hospitality at the FSU Dedman School of Hospitality, Florida State University) to an earlier draft of this article. Furthermore, the authors like to acknowledge Lerzan Aksoy, the co-editor of this special issue, the two anonymous reviewers, and the following individuals for their valuable input during the various stages of this research project (in alphabetical order): Ashish Modak (Regional General Manager, LUX* Belle Mare, LUX* Grand Gaube and LUX* Grand Baie), Smita Modak (Group Training Manager, The Lux Collective), Ron Kaufman (bestselling author on uplifting service), Werner Kunz (Professor of Marketing, University of Massachusetts Boston), and Wilhelm Taurel (consultant and expert on B2B service productization). Finally, the first author is grateful to Nicole Tee (Director, MBA Programmes Office) and Joane Yuen (Head, Experiential Learning) as he learned a lot from accompanying their journey towards productizing various experiential learning offers and the MBA Club Ecosystem of the NUS MBA Programme at the National University of Singapore.
} 


\title{
Service Products and Productization
}

\begin{abstract}
Many services are difficult to understand and communicate, and as a result, difficult to position, differentiate, and sell. While important, understanding services as well-defined products has hardly received research attention although doing so offers a host of potential benefits. This conceptual article makes the following contributions. First, it synthesizes the literature to develop a better understanding of service productization as a process that transforms variable, ad-hoc services and service products into well-defined service products (i.e., 'productized services'). Second, it advances that well-defined service products are (1) specified (i.e., have a formalized value proposition and are configured, standardized, systemized, and often also modularized and bundled), (2) branded (i.e., have a name, symbol, or design), (3) and priced (i.e., have clearly stated prices). Third, this article advances managerial practice by exploring the concepts and tools available to productize services and outlining managerial benefits and potential drawbacks of highly productized services.
\end{abstract}

Keywords: Service product; productization; specification; standardization; branding; pricing 


\section{Service Products and Productization}

\section{Introduction}

"Anyone can make something complex; but it takes a genius to make something simple”-

Albert Einstein.

Many services are complex, intangible, and not clearly defined which can make it challenging for customers to distinguish between different offerings and understand what they are getting for their money. As a result, such services are difficult to position, differentiate, and sell. Resonating this dilemma, Grönroos (2020) suggested that services should be treated as concrete objects, albeit intangible ones, and that they need to be marketed very much like tangible products. These are powerful suggestions, however, academic research on clearly defined service products is scarce (Grönroos, 2020; Wirtz, 2021).

Better knowledge on service products could help service managers overcome many challenges. For example, previous research indicates that when the content of a service offering remains fuzzy and constantly varying, many service managers struggle with communicating, promoting, and pricing services (Clemes, Mollenkopf, \& Burn, 2000) as well as with running efficient service operations (Verma, 2000). What is more, customers often find it difficult to grasp a service provider's value propositions, necessitating more concrete and clearly specified offerings that would reduce the sense of ambiguity and customer risk perceptions (Jaakkola, 2011). Consider, for example, the fully standardized group fitness classes by Les $\mathrm{Mills}^{2}$ or the children's birthday party packages by McDonald's. ${ }^{3}$ Both comprise clear sets of options to choose from, standardized delivery formats, and physical infrastructures that reinforce the

\footnotetext{
${ }^{2}$ https://www.lesmills.com/nordic/workouts/fitness-classes

${ }^{3} \mathrm{https}: / /$ mymcdonaldsparty.com
} 
service brand, which make it easy for the customer to understand what the service entails. However, this approach is still not wide spread or well understood. Both academics and practitioners would benefit from a better view on how to create, promote, and deliver services that are more clearly defined rather than something fuzzy that is inadequately specified, vaguely communicated, and poorly understood.

One powerful approach to developing more concrete, object-like service products is the productization of services, which to date has received limited research attention. The handful of studies on productization have focused on a specific aspect of this concept such as modularization, or its application in a narrow context such as professional services (see e.g. Jaakkola, 2011; Valtakoski \& Järvi, 2016; Tuominen \& Martinsuo, 2019). As Harkonen, Haapasalo, \& Hanninen (2015) concluded in their review article, "the discussion on the productization of services in the published journal articles seems to be somewhat limited and lacking depth" (p. 70). What remains missing is an overarching framework for service productization that is applicable across service industries holistically and can guide further research in the area.

Therefore, the purpose of this article is to provide academics and practitioners alike with a better understanding and guidance on what well-defined service products are and how they can be crafted using service productization. To do this, we synthesize the extant literature on service productization, service products, and related fields (c.f., Jaakkola, 2020). With this conceptual article, we make the following contributions. First, we develop a better understanding of what exactly is service productization. Second, we advance that well-defined service products (i.e., productized services) have three key characteristics: they are (1) specified (i.e., have a formalized value proposition, are configured, standardized, systemized, and often also 
modularized and bundled), (2) branded (i.e., have a name, term, symbol, or design, and are externally identifiable and distinctively perceived by these linguistic, visual, and tangible cues), (3) and priced (i.e., have clearly stated, communicated, and committed prices that can include rate fences and tiering). Third, we explore the concepts and tools that are available to productize services, that is, to transform variable, ad-hoc services and service products into well-defined service products. We conclude with a discussion of the managerial benefits and potential drawbacks of highly productized services.

\section{Why should firms care about productization? The case of LUX* Resorts \& Hotels}

To ground our analysis of the content and relevance of service productization, we start with an illustrative example. Specifically, we use LUX* Resorts \& Hotels as a mini-case study (Wirtz \& Kaufman, 2016; Wirtz and Lovelock, 2016, pp728-743; Wirtz, 2021) to show a successful service productization initiative and its benefits. LUX* engaged in service productization to support its overall brand positioning (i.e., "Lighter.Brighter" being more simple, fresh and sensory than competitors) and value proposition ("help people celebrate life"). Its productized services included those that addressed specific customer needs (e.g., various packages for weddings and couple retreats), a number of branded experiences there were deployed system-wide (e.g., each of its resorts had a Cinema Paradiso and Café LUX*), and destination-specific offerings (e.g., its "A Mauritian Rum Adventure" as a branded experience curated around local rum, Mauritius' national drink).

Using the service productization approach, even for specific experiences in its resorts that were not sold separately but were part of the overall resort experience (e.g., Cinema Paradiso), was instrumental for LUX*'s turnaround from virtual bankruptcy to profitability and growth. It 
helped to build the hotel chain's innovation culture and to better differentiate its various offerings. To illustrate, LUX* developed and transformed a number of generic services and ideas into well-defined service products, which were internally referred to as "Reasons to Go to LUX*" (or "RTGs" in short). In simple terms, a RTG is a branded experience designed to make guests feel different and special. Examples include the LUX* Cinema Paradiso, a branded movie screening experience at the beach, and Café LUX* with its own ethically sourced coffee blend freshly roasted on-site, and served in its branded Café LUX* outlets. Both RTGs are delivered in all LUX* resorts around the world. What then is the difference to movie screening services and gourmet coffees offered by other 5-star resorts that did not productize their services?

The difference becomes clear when one examines the development, specification, and delivery of productized services. LUX* formed teams within each of its resorts that were tasked with developing RTGs. These teams observed and talked with guests, scanned the Internet, looked at what other resorts were doing, and generated numerous ideas this way. One of these ideas was a beach movie screening experience that the team developed into a branded 'Cinema Paradiso' service product. Developing this product entailed specifying its visual appearance, format, and content for the customer as well as the material elements needed to deliver the value proposition. For example, Cinema Paradiso included an early evening screening for children and a later show for adults, a movie experience had to have popcorn and ice cream for children, and a glass of wine for the evening show. It included beanbags and comfortable cushions to lie on the beach, and wireless headphones that allowed a high-quality audio experience outdoors without disturbing other guests, and more. The difference to other resorts' outdoor movie screening is that at LUX*, a team sat together to formally specify, test, and fine-tune this experience, develop a brand for it, and once it was deemed 'right' in one or more pilot sites, the format was specified 
and blueprinted, and then rolled out system-wide. As a result, every LUX* resort had the same high-quality, innovative Cinema Paradiso.

The advantages of this productization for key stakeholders are manifold. It enables the firm to engage in systematic service development projects, as opposed to incremental development that is typical for less specific services that tend to develop organically (c.f. Jaakkola \& Hallin, 2018). Employees can better understand these productized services, explain them more effectively (e.g., almost every LUX* employee can describe the various RTGs to guests with enthusiasm and confidence), and know how to consistently and system-wide deliver them at high quality. Importantly, productization facilitates positioning and differentiating services and makes them easier to market, sell, and scale.

This case serves to illustrate benefits of developing and putting well-defined service products into practice through the process of productization. In the following section, we derive key definitions for this central process.

\section{What is service productization?}

Although the term 'service product' is used in the literature, it does not necessarily indicate productization because this term is generally used as a synonym for service offering. Thus, service products may be more or less productized. Prior research on productization focuses on software, technology, services, and even products (Harkonen, Haapasalo, \& Hanninen, 2015). A few studies explicitly focus on service productization (e.g., Jaakkola, 2011; Harkonen, Tolonen \& Haapasalo, 2017), with others addressing nuanced elements of productization, such as modularization (Gremyr, Valtakoski, \& Witell, 2019), and formalization (Tuominen \& Martinsuo, 2019). Furthermore, although 
standardization and service quality research has focused on some aspects of productization (e.g., how to deliver consistently high quality), it has not explored how these standardized and high quality services could be 'packaged', marketed, and sold as object-like, welldefined service products (Grönroos, 2020; Wirtz, 2021). Extant literature thus features inconsistent terminology and many loose ends, which inhibit the theoretical development of this concept.

To synthetize extant knowledge, we reviewed how productization has been previously defined (Table 1). This review suggests that service productization can be understood as the process of transforming variable, ad-hoc services and service products into concrete, well-defined service products through specific approaches and tools. The key dimensions of productization identified in extant literature focus on addressing core challenges inherent in many services, that is, their intangibility and lack of comprehensibility, standardization, formalization, systemization, repeatability, configuration, modularization, and bundling. 
Table 1. Descriptions, definitions, and key dimensions of service productization

\begin{tabular}{|c|c|c|}
\hline Authors & Descriptions and Definitions & Key Dimensions \\
\hline $\begin{array}{l}\text { Harkonen, Tolonen, \& } \\
\text { Haapasalo (2017) }\end{array}$ & $\begin{array}{l}\text { - Successful productization results in a service product that can be sold, } \\
\text { delivered and invoiced. A company can have a number of service products that } \\
\text { form a product family of services. } \\
\text { - Productization also leads to the systematizing and tangibilizing of the service } \\
\text { offering and related processes, while creating a level of formalization. } \\
\text { Formalization in this context may entail the standardization of service } \\
\text { components and processes. }\end{array}$ & $\begin{array}{l}\text { - 'Tradable' units of service } \\
\text { - Family of service products } \\
\text { - Systematization } \\
\text { - Tangibilization } \\
\text { - Formalization } \\
\text { - Standardization }\end{array}$ \\
\hline $\begin{array}{l}\text { Valtakoski, \& Järvi } \\
\text { (2016) }\end{array}$ & $\begin{array}{l}\text { - Service productization is a process of knowledge transformation along two } \\
\text { dimensions: from tacit to explicit, codified knowledge, and from individual } \\
\text { employee knowledge to organizational knowledge. } \\
\text { - A successfully productized service is ready to be replicated throughout the } \\
\text { organization. }\end{array}$ & $\begin{array}{l}\text { - Replicability } \\
\text { - Knowledge codification } \\
\text { - Knowledge transfer from tacit to explicit } \\
\text { - Knowledge transfer from individual employees } \\
\text { to the organization }\end{array}$ \\
\hline Andreini et al. (2015) & $\begin{array}{l}\text { - Productization suggests moving from a service-dominant to a good-dominant } \\
\text { logic, aiming at objectivizing, standardizing, and packaging services. } \\
\text { - The good-dominant logic approach introduces manufacturing tenets into the } \\
\text { world of services, transforming intangible offerings into more objectified } \\
\text { proposals. }\end{array}$ & $\begin{array}{l}\text { - Objectivization } \\
\text { - Standardization } \\
\text { - Packaging }\end{array}$ \\
\hline Nagy (2013) & $\begin{array}{l}\text { - Productization refers to the activity where service companies provide more } \\
\text { product-like solutions through systemization of their components. }\end{array}$ & $\begin{array}{l}\text { - Solutions } \\
\text { - Systemization } \\
\text { - Modularization (components) }\end{array}$ \\
\hline
\end{tabular}




\begin{tabular}{|c|c|c|}
\hline $\begin{array}{l}\text { Aapaoja, Kujala \& } \\
\text { Pesonen (2012) }\end{array}$ & $\begin{array}{l}\text { - The main output of productization is bundling offerings and deliveries } \\
\text { together in well-defined packages so that the expectations of customers are } \\
\text { better fulfilled. }\end{array}$ & $\begin{array}{l}\text { - Bundling } \\
\text { - Packaging }\end{array}$ \\
\hline Jaakkola (2011) & $\begin{array}{l}\text { - Servitization incudes (1) specifying and standardizing the service offering, (2) } \\
\text { tangibilizing and concretizing the service offering and professional expertise, } \\
\text { and (3) systemizing and standardizing processes and methods. } \\
\text { - Productization is used to translate the abstract service and its creation into } \\
\text { concrete exchangeable objects and controllable processes. }\end{array}$ & $\begin{array}{l}\text { - Specification } \\
\text { - Standardization } \\
\text { - Tangibilization, concretization } \\
\text { - Systemization } \\
\text { - Creation of 'exchangeable' units of service }\end{array}$ \\
\hline $\begin{array}{l}\text { Valminen \& Toivonen } \\
\text { (2012) }\end{array}$ & $\begin{array}{l}\text { - Productization' refers to an activity where the service offering is made more } \\
\text { 'product-like' through a systematization of its components. The aim is the } \\
\text { clarification of the nature of a service as a commercially valuable commodity. }\end{array}$ & $\begin{array}{l}\text { - Systemization } \\
\text { - Definition } \\
\text { - Creation of a 'commercially valuable' offer }\end{array}$ \\
\hline Current study & $\begin{array}{l}\text { - Service productization is the process of transforming variable, ad-hoc services } \\
\text { and service products into well-defined service products that are specified, } \\
\text { branded, and priced so that they address a specific customer need (see Table } 2 \\
\text { for details). }\end{array}$ & $\begin{array}{l}\text { - Specification } \\
\text { - Branding } \\
\text { - Pricing }\end{array}$ \\
\hline
\end{tabular}

Note: Articles are listed in reverse chronological order of publication and alphabetically in the same year of publication. 
While the extant definition covers the specification of services (i.e., defining, formalizing and standardizing service elements, which is broadly discussed in the productization literature), our definition presented in Table 1 augments the concept of productization with branding and pricing. In prior definitions, branding is merely implied in dimensions such as 'packaging' and 'tangibalization'. Similarly, a number of definitions point towards making services commercially ready and tradeable, but they do not mention pricing explicitly. The definition offered in this paper covers these dimensions explicitly.

Branding is a core component of a product in virtually all marketing texts (e.g., Kotler \& Armstrong, 2021) and is clearly palpable in many successfully productized services (e.g., see our LUX* case earlier). The literature on service pricing and revenue management too uses tools such as rate fences and tiering of service to define service offers for specific customer segments with differing price sensitivities and needs (Kimes \& Wirtz, 2015). That is, the branding and pricing literatures address similar issues from their disciplines' perspectives and examine how to price and sell specific offerings with well-defined content. The important roles branding and pricing play in productization are nicely expressed by a manager in Jaakkola's (2011) study: "We gave the service a brand name and a clear description of the content, price and even the delivery time. We developed some promotional material through which we communicate the essential benefit of the service via illustrations and slogans. ... It is really an icebreaker in the sales situation!” (p. 226). 


\section{What are productized services?}

Why does it seem so difficult to productize services? The answer lies in the structurally different nature of service products compared to physical products, which is reviewed next. This is followed by a discussion on what exactly are productized services.

\subsection{What is a service product?}

'Product' is often used as an umbrella term, commonly defined as a consistent bundle of output or a market offering that provides the ability to differentiate one bundle of output from another (AMA, 2021). In a manufacturing context, the concept is easy to understand as the output is embodied in a physical product, that is, a manufactured tangible good that customers buy and own. A service product also represents a marketing offering but is structurally different: It refers to a performance that is experienced rather than owned. Even when bearing physical elements (e.g., a surgically implanted pacemaker or a replacement part installed in a car), a significant portion of the value added is in the service (e.g., expert labor and the use of specialized equipment; Lovelock \& Gummesson 2004). As such, a service product comprises all the elements of the service performance, both physical and intangible, that create value for customers (Harkonen, Tolonen, \& Haapasalo, 2017).

The extant literature converges around an understanding of service products as performances that include an exchange of value between the provider and the customer (Wirtz \& Lovelock, 2016, p. 21). This process of value exchange can be mutually defined and negotiated before and even during a service encounter between an organization and its customers one at a time (i.e., a real-time process). In contrast, most physical products are configured and assembled (i.e., are pre-defined and fully specified) before being sold and therefore are almost by definition 
highly specified, especially so for mass-produced manufactured goods. This structural difference between service products and physical products explains why the former are generally less productized than the latter. In particular, rarely is a service product designed with the scrutiny we know from manufactured goods' engineering and development (c.f., Kalyanaram \& Krishnan, 1997).

Nevertheless, service firms can still specify and differentiate their offerings in a similar fashion using the various configurations (or 'models') as is done by manufacturers. The objective of this productization process is to design service experiences that address specific customer needs and wants, are distinct, and can be easily differentiated from other offerings (Wirtz \& Lovelock, 2016, p. 124), just like tangible goods. These configurations can refer to any of the three components entailed in a service offering (Jaakkola, 2011; Wirtz \& Lovelock, 2016, p. 125): its core product (e.g., a rejuvenating spa treatment), supplementary services (e.g., making reservations, providing consultation, and making payment), and its delivery processes (e.g., the way the core and supplementary services are executed).

Importantly, productization can be viewed on a continuum where a service product can range from being hardly productized (i.e., is variable and delivered on an ad-hoc basis) to highly productized (i.e., is well-defined with a high specification, a brand, and clearly indicated price). Many service firms already offer highly productized service products. For instance, travel insurance and credit card products are carefully designed to contain distinct service content (i.e., are specified), are given a name and logo (i.e., are branded), and are priced (e.g., each service product has a clearly stated price). Furthermore, the bundling of core and various supplementary services into "packages" that suit particular purposes is widely used. For example, many hotels offer pre-specified service bundles for different purposes such as weddings, corporate meetings, 
and get-away couple weekends. The get-away weekend service product may include various elements like a couple's spa, a romantic candle-light dinner, and breakfast, is likely to have its own name advertised on the hotel's website and booking engine, and has a price attached to it. Table 2 provides a summary of the discussion on service products in this section, and the description and definition of productized services, which are developed in the following sections. 
Table 2. Definitions and description of service products and productized services

\begin{tabular}{|c|c|}
\hline Terms & Definitions and descriptions \\
\hline Service product & $\begin{array}{l}\text { - A service product comprises all the elements of a service performance, both } \\
\text { physical and intangible, that create value for customers (Harkonen, Tolonen, \& } \\
\text { Haapasalo, 2017). } \\
\text { - Is a service offering that delivers a bundle of benefits (Harkonen, Tolonen, \& } \\
\text { Haapasalo, 2017) which: } \\
\text { C Consists of three components: the core product, supplementary services, and the } \\
\text { service delivery process (Jaakkola, 2011; Wirtz \& Lovelock, 2016, p. 125). } \\
\text { The core product delivers the principal benefits and solutions a customer seeks } \\
\text { (e.g., a rejuvenating spa treatment or a car repair). } \\
\text { Supplementary services facilitate the use of the core service (e.g., order taking } \\
\text { and payment) or enhance its value (e.g., consultation and hospitality). } \\
\text { The service delivery process refers to how the service is delivered and shapes } \\
\text { the customer experience. } \\
\text { - May or may not be productized; there is a continuum from service products that are } \\
\text { hardly productized (i.e., are not well-defined) to those that are highly productized } \\
\text { (i.e., are well-defined). }\end{array}$ \\
\hline Productized service & $\begin{array}{l}\text { - Is a well-defined service offering that is specified, branded, and priced so that it } \\
\text { addresses a specific customer need. } \\
\text { - Is the outcome of a service productization process. } \\
\text { - Specified means that the service has a defined value proposition and attributes. This } \\
\text { can be achieved by: } \\
\text { O Understanding, defining and expressing the object of value exchange (e.g., } \\
\text { defining and formalizing value propositions and attributes); } \\
\text { Dismantling the overall service into separate units and re-combining them (e.g., } \\
\text { modularizing services and bundling service units) into solutions (e.g., packages } \\
\text { or bundles that address specific customer needs (Jaakkola, 2011). } \\
\text { Reducing the variability of the service (e.g., systemizing and standardizing } \\
\text { processes). } \\
\text { - Branded means that the service product has a name, term, symbol, or design, and is } \\
\text { externally identifiable and distinctively perceived by linguistic, visual, and tangible } \\
\text { cues. It makes a service, its value proposition, and quality more easily understood } \\
\text { and recognized (i.e., mentally tangible) and physically identified (i.e., physically } \\
\text { tangible). } \\
\text { - Priced means that the price is clearly stated, committed, and communicated as part } \\
\text { of the service product (i.e., the price is not 'negotiated' or determined transaction } \\
\text { by transaction, or even during the service encounter). } \\
\text { Revenue management tools (e.g., rate fences) and tiering of service are often } \\
\text { used to define service products for specific customer segments with differing } \\
\text { price sensitivities and needs (Kimes \& Wirtz, 2015). } \\
\text { Price can be zero for services products that are not separately traded (e.g., } \\
\text { Cinema Paradiso in our LUX* case example). These service products do not } \\
\text { have a dollar value attached to them; their price is effectively stated as zero and } \\
\text { customers understand this. }\end{array}$ \\
\hline
\end{tabular}




\subsection{What are the characteristics of productized services?}

The service productization literature offers a rich conceptual contribution to the 'how' of making services more product-like (e.g., Goldstein et al., 2002; Harkonen, Tolonen, \& Haapasalo, 2017; Jaakkola, 2011), and holds how service productization moves service products towards becoming concrete units of deliverables to customers rather than something of unspecified nature and quantity (see Table 1). However, the 'what,' the desired end state of this process perspective has garnered little attention (c.f., Grönroos, 2020; Wirtz, 2021). This is an important gap in the literature as understanding and defining the concept of well-defined service products (i.e., the 'what') is a prerequisite for making effective use of the productization concepts and tools.

Based on the discussion in the following sections, we propose that productized services should be (1) specified, (2) branded, and (3) priced. These three characteristics make service products well-defined and tailored to address and deliver definable value to customers. Regarding (1) specification, we reviewed the extant productization literature as described next. For (2) branding and (3) pricing, we reviewed the branding and pricing literatures, which have not been considered in the productization literature much, if at all, but are relevant because they address similar issues from their disciplines' perspectives (e.g., how to communicate, price and sell predefined service offerings).

Specified. Specified means that the service product has a defined value proposition, leading to overall specified service characteristics. It includes a specification of what is to be done for the customer (i.e., the core service) and how this is to be achieved (i.e., through supplementary services and service delivery processes; Jaakkola, 2011; Wirtz \& Lovelock, 2016, p. 125). This is facilitated by understanding, defining, and formalizing the value proposition, 
dismantling the overall service into separate units and re-combining them into solutions (e.g., configuring, modularizing services and bundling service units), and reducing the variability of the service (e.g., by systemizing and standardizing processes) (Jaakkola 2011; Valtkowski \& Järvi, 2016; Harkonen, Tolonen, \& Haapasalo,2017).

Branded. Aaker $(1991,1996)$ defined brands as names, terms, symbols, or designs to signal and communicate market offerings to customers. While for "packaged goods, the product is the primary brand" (Berry, 2000, p. 128), service experiences are more procedural, referring to "cognitive, affective, and behavioral reactions associated with a specific service event" (Padgett \& Allen, 1997, p. 51). Thus, service branding addresses the creation and maintenance of the customer's overall mental picture associated with a service.

Yet, services are often hard to conceptualize mentally due to their intangible nature (McDougall \& Snetsinger, 1990). Hence, tangibalization, a key mechanism described in the service productization literature, is central to facilitate service branding. It connotes adding tangible features to service products such as promotional material like brochures, displays or leaflets to illustrate the service processes (Jaakkola, 2011), or guiding and shaping customer experiences and quality perceptions through the servicescape (Bitner, 1992).

Importantly, tangibilization does not only entail a physical but also a mental component. The mental component increases customers' ability to visualize or picture a service product and creates consistent mental representation in the customers' perception (McDougall \& Snetsinger, 1990). Specifically, communicating mental cues such as "Dine under the stars" (Ayers Rock Resort, Australia) can make a service product mentally graspable. Taken together, branding makes a service product identifiable and distinctively perceived by customers and employees through linguistic, visual, and tangible cues. As such, it makes a service and its value proposition 
physically identified (i.e., enhancing physical tangibility) and more easily understood and recognized (i.e., enhancing mental tangibility).

Priced. Service pricing is based on various objectives like return-on-investment, market share increase, or long-term competitiveness (for an overview see Avlonitis, Indounas, \& Gounaris, 2005). Furthermore, we advance that prices that are clearly stated, communicated and committed as part of a product (i.e., the price is not 'negotiated' or determined transaction by transaction) are an important part of a productized service offer. Revenue management tools (e.g., rate fences that specify clearly what a particular offer entails) and tiering of service (e.g., prices that are linked to specific performance attributes such as a two-hour versus a 24 -hour response time) are often used to define priced service products (Kimes \& Wirtz, 2015).

We also propose that it is important to distinguish between service products that are separately traded and have a price attached to them and not separately traded services (i.e., they are not billed and paid by the customer). Many products - both physical goods and service-based - involve service that is not traded but just provided as part of a customer journey or a relationship with the customer without additional payment. In contrast to traded service products, these non-traded services have received little if any research attention on whether and how they could be productized. However, as shown in our LUX* case study with the example of Cinema Paradiso, productization can be applied to move service towards well-defined service products even if they do not have a dollar value attached to them, but their 'price' can still be considered specified; it is zero. In sum, we advance that well-defined service products have an upfront stated and communicated price, which can be zero in the case of not separately service products.

Contrasting service products with different degrees of productization. Table 3 illustrates the three characteristics of well-defined service products and shows how these 
characteristics together make a service product well-defined. Furthermore, we argue that the degree of productization of a service should be understood as a continuum ranging from low (i.e., the service product is not well-defined) to high levels of productization (i.e., it is welldefined by being highly specified, having a brand, and being clearly priced).

Table 3. Characteristics of well-defined service products

\begin{tabular}{|c|c|c|}
\hline $\begin{array}{l}\text { Service } \\
\text { product } \\
\text { characteristics }\end{array}$ & $\begin{array}{l}\text { Low degree of productization } \\
\text { (not well-defined service product) }\end{array}$ & $\begin{array}{l}\text { High degree of productization } \\
\text { (well-defined service product) }\end{array}$ \\
\hline Specified & $\begin{array}{l}\text { - Not targeted to address specific customer } \\
\text { needs and wants. } \\
\text { - Contents, duration, and deliverables are not } \\
\text { clear before the service has been produced. } \\
\text { - Service specifications and delivery depend on } \\
\text { customer and employee communications and } \\
\text { interactions before purchase and during service } \\
\text { delivery. } \\
\text { - Service is delivered depending on employee } \\
\text { skills and preferences, and customer requests. } \\
\text { - Each service transaction may be executed } \\
\text { differently. } \\
\text { - Customers do not understand well what they } \\
\text { will receive when they search and purchase } \\
\text { the service. } \\
\text { Examples: } \\
\text { - The features of a birthday celebration in a } \\
\text { family restaurant is determined by customer } \\
\text { requests and employee willingness, ability, } \\
\text { and creativity. } \\
\text { - A complicated treatment a hospital evolves } \\
\text { with the medical experts' recommendations } \\
\text { and patient discussion. } \\
\text { - Meeting an architect without knowing the } \\
\text { extent or process of getting a house designed. }\end{array}$ & $\begin{array}{l}\text { - Highly specified solutions that were developed to } \\
\text { address specific customer needs and wants. } \\
\text { - Service specifications, delivery and level of } \\
\text { customization are pre-determined. } \\
\text { - Service process is designed and specific phases are } \\
\text { executed in the same manner. } \\
\text { - Service is delivered by employees with the required } \\
\text { skills to produce the service as specified. } \\
\text { - Customers understand well what they will receive } \\
\text { when they search and purchase the service. } \\
\text { Examples: } \\
\text { - A McDonald's children birthday party consists of a } \\
\text { clearly defined bundle that customers can customize } \\
\text { based on specified opt-in, opt-out modules. } \\
\text { - Annual health check-up that states exactly what is } \\
\text { covered, how long it takes, the process, and the test } \\
\text { results, reports and consultation the customer will } \\
\text { receive. } \\
\text { - Cinema Paradiso specified exactly what a beach } \\
\text { movie screening experience entails (see LUX* case } \\
\text { study). } \\
\text { - An architect's service package for house designing } \\
\text { that explicates the steps of the process needed, } \\
\text { estimated time line, and different service levels or } \\
\text { modules. }\end{array}$ \\
\hline
\end{tabular}




\begin{tabular}{|c|c|c|}
\hline $\begin{array}{l}\text { Service } \\
\text { product } \\
\text { characteristics }\end{array}$ & $\begin{array}{l}\text { Low degree of productization } \\
\text { (not well-defined service product) }\end{array}$ & $\begin{array}{l}\text { High degree of productization } \\
\text { (well-defined service product) }\end{array}$ \\
\hline Branded & $\begin{array}{l}\text { - Does not have a brand, name or logo. } \\
\text { - Intangible elements have not been tangibilized } \\
\text { or visualized. } \\
\text { - Does not have a distinct or differentiated value } \\
\text { proposition. } \\
\text { Examples: } \\
\text { - Birthday celebration in a family restaurant. } \\
\text { - Many hospital services such as complicated } \\
\text { treatments. } \\
\text { - Generic beach movie screening services } \\
\text { offered in many resorts. }\end{array}$ & $\begin{array}{l}\text { - Has a distinctive and recognizable name, symbol, or } \\
\text { design, and is identifiable by these linguistic, visual, } \\
\text { and tangible cues. } \\
\text { - Intangible elements are tangibilized through physical } \\
\text { and mental cues. } \\
\text { - Has a distinct and differentiated value proposition that } \\
\text { is easy to understand and recognize. } \\
\text { Examples } \\
\text { - McDonald's children birthday parties are branded as } \\
\text { McCelebrations with a logo. } \\
\text { - Many hospitals have annual health check-ups with } \\
\text { different screening packages that have a name, logo, } \\
\text { and visual material to concretize their content. } \\
\text { - LUX's Cinema Paradiso has a brand name and fixed } \\
\text { material elements that convey a differentiated value } \\
\text { proposition. }\end{array}$ \\
\hline Priced & $\begin{array}{l}\text { - Itemized prices may be available but the total } \\
\text { cost of addressing specific customer needs are } \\
\text { not stated clearly. } \\
\text { - Prices can often not be computed before } \\
\text { purchase (e.g., car repair or hospital stay). } \\
\text { - Prices can often be negotiated (e.g., a } \\
\text { consulting project). } \\
\text { Examples: } \\
\text { - In hospitals, the final price to be paid is often } \\
\text { not stated prior to treatment. } \\
\text { - Car or computer repair where the price is } \\
\text { often not set prior to the repair. } \\
\text { - An architect's design project invoiced by } \\
\text { billable hours on a 'best effort basis' and not } \\
\text { pre-defined deliverables. }\end{array}$ & $\begin{array}{l}\text { - Prices are clearly stated for specific service products } \\
\text { that address a particular customer need and want. } \\
\text { - Prices are stated, committed, and agreed before } \\
\text { purchase. } \\
\text { - Revenue management and its rate fences can be used } \\
\text { in capacity-constraint services to tailor products to } \\
\text { specific customer segments with different price } \\
\text { sensitivities, and need and want bundles. } \\
\text { - Tiering can be used where different performance } \\
\text { levels are priced differently. } \\
\text { Examples: } \\
\text { - McDonald's children birthday party and productized } \\
\text { annual health check-ups have clearly stated prices for } \\
\text { recommended bundles. Prices for adding or dropping } \\
\text { parts of the package are also clearly stated. } \\
\text { - A car repair service with a 'saver plan' for a 2-day } \\
\text { response time, a 'standard plan for } 24 \text {-hour, and } \\
\text { 'premium plan' for a 1-hour response time. } \\
\text { - An architect's design package that has a total price or } \\
\text { a set of prices for different service levels and modules } \\
\text { that the customer can choose. }\end{array}$ \\
\hline
\end{tabular}




\section{How is service productization achieved?}

In this section, we examine the process of service productization. Thus, after answering the 'what', we are turning towards the 'how' of creating well-defined service products and describe the approaches and tools available to do this. As shown in the previous section, a service product consists of the core product, supplementary services, and the service delivery process (Jaakkola, 2011; Wirtz \& Lovelock, 2016, p. 125) that can be productized through specifying, branding, and pricing. In addition, we advance that service firms need to build an infrastructure that is supportive of delivering its productized services (Edvardsson \& Olsson, 1996; Jaakkola, 2011; Harkonen, Tolonen, \& Haapasalo, 2017). Figure 1 illustrates this 'big picture' framework, which is used to structure our discussion in the following sections on how productization of services can be achieved. 
Figure 1. Key productization approaches and tools

\section{Productization Approaches and Tools}

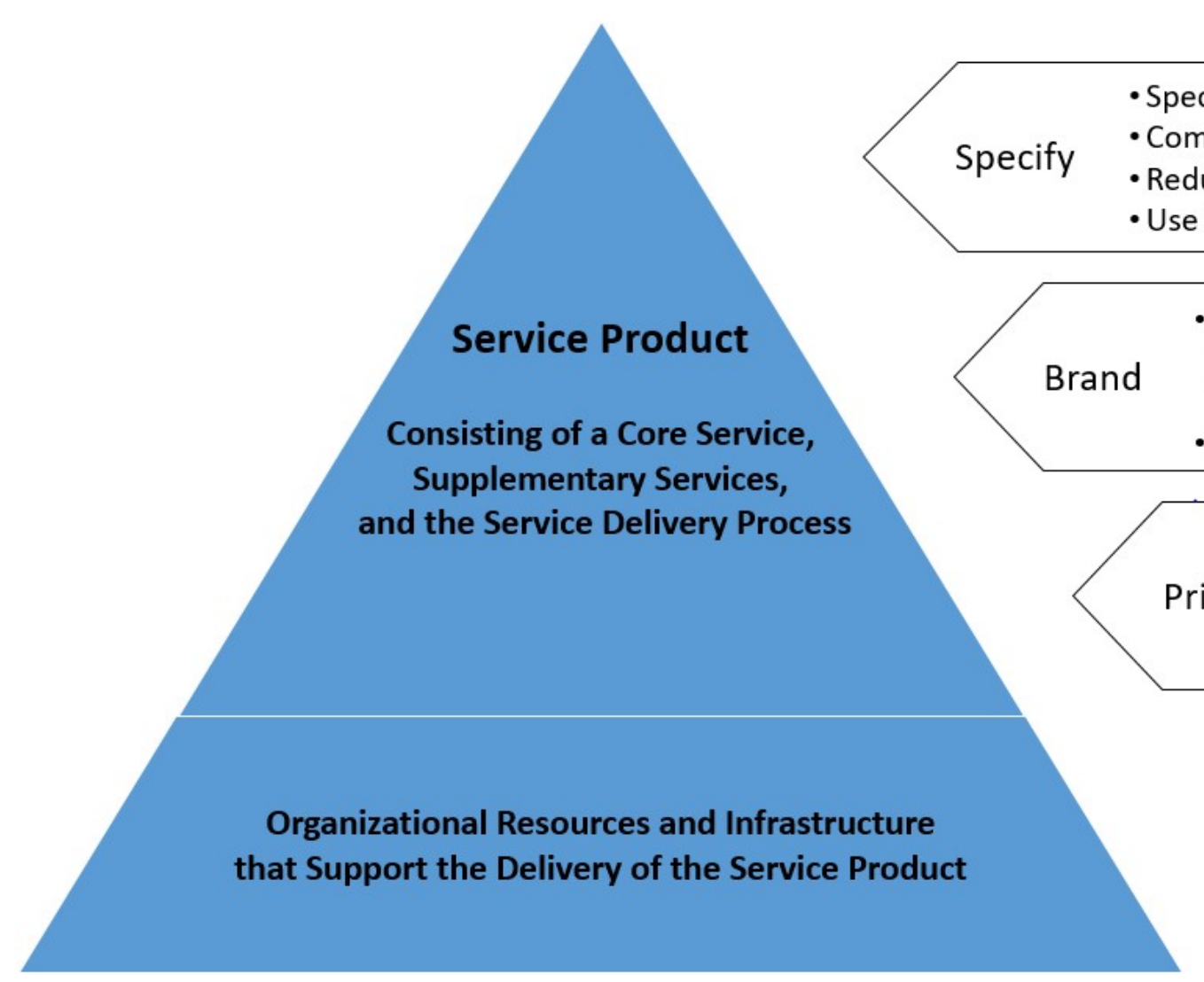

- Specify and formalize the value proposition

Combine service elements through modularization \& bundling

- Reduce variability through standardization

- Use flowcharting or blueprinting to visualize and standardize processes

- Develop names, terms, symbols, and designs to create mental pictures to tangibilize the service product $\&$ its value proposition, both physically and mentally

- Build a brand architecture for the firm, its products, and experiences

- Develop prices for service products that are stated upfront, clearly communicated and committed.

- Use rate fences and tiering of service to specify the offer (note that for not separately traded services the price is zero)

Develop and codify supportive methods, tools, and materials 


\subsection{Specification}

Specification details what is to be done for the customer (i.e., the core service) and how this is to be achieved (i.e., through supplementary services and service delivery processes; Jaakkola, 2011; Wirtz \& Lovelock, 2016, p. 125). Specification is facilitated by formalizing the value proposition, modularizing services and bundling service units, and reducing the variability of the service through standardization (Jaakkola, 2011; Valtakoski \& Järvi, 2016; Harkonen, Tolonen, \& Haapasalo, 2017).

Specifying formalized value propositions helps to differentiate across — and meet specific needs of $\longrightarrow$ specific customer segments (Rahikka, Ulkuniemi, \& Pekkarinen, 2011). Modularization has originally been applied to physical products (Ma \& Kremer, 2016; Pil \& Cohen, 2006). A well-known example is Ikea with its standardized table legs that can be combined with multiple standardized table plates. Transferred to services, modularization means to decompose a complex service into single, standardized pieces that can be flexibly recombined, thus enabling customization at low cost (Rahikka, Ulkuniemi, \& Pekkarinen, 2011). When a service entity is modularized into smaller, compatible elements, the customer can see what the entity comprises, and it becomes possible for the provider and the customer to jointly put together a bundle that fits the customer's needs. When productizing a service, firms can then develop separate, standardized modules and combine them to a limited number of pre-specified service products (for a review on the decomposition and subsequent modularization of services, see Eissens-van der Laan, et. al., 2016).

Standardization is a core concept for specifying service products and aims "to formalize both service content and service process" (Lehtonen, Järvi, \& Tuominen, 2015, p. 4). However, services differ greatly in terms of how much variation their service processes entail. While some 
services follow a relatively standard process (e.g., public transport), others may vary considerably according to the resources and individual judgment by employees and customers (e.g., consultancy services). Service productization involves standardizing towards a more unified approach both in terms of customer-facing and internal, back-stage service operations (Jaakkola, 2011). Although some processes typically require variation, more specifically defined and planned processes can make routine processes easier and faster, and facilitate resource allocation and planning (Harkonen, Tolonen, \& Haapasalo, 2017).

Standardizing is typically conducted by identifying and developing repeatable elements in the service processes that are used in many customer projects (Lehtonen, Järvi, \& Tuominen, 2015). The service literature offers several means of service process development, with flowcharting and service blueprinting (Bitner, Ostrom, \& Morgan, 2008; Fließ \& Kleinaltenkamp, 2004) being probably the most widely-used tools. Service blueprinting visualizes end-to-end service processes, depicting a chronological sequence of the customer-firm interactions on the horizontal axis and different zones of actions on the vertical axis (Bitner, Ostrom, \& Morgan, 2008). As such, it allows for the standardization of front office processes along the customer journey and links them to corresponding, standardized back-office processes (Salunke, Weerawardena, \& McColl-Kennedy, 2013). From the viewpoint of productization, the goal is not only to develop efficient processes but to also move from ad hoc customer service to scalable formats for providing the service.

It should be noted that standardization does not mean that the service outcome is always the same. Instead, standardization means specifying an outline of the contents of each element of the service product as well as describing the expected outcomes (Jaakkola, 2011). In other words, complete standardization of service is not the goal here, but rather the development of 
basic processes and structures that can be complemented with customer-specific elements (Lehtonen, Järvi, \& Tuominen, 2015), whereby different levels of empowerment can be given to employees to tweak and customize the service (Tuominen \& Martinsuo, 2019).

\subsection{Branding}

Branding is a core component of marketing and well covered (e.g., Kotler \& Armstrong, 2021). A major challenge with branding services evolves from their intangibility, which is widely accepted in the literature (Shostack, 1977; Zeithaml, Parasuraman, \& Berry, 1985). Accordingly, branding as a key productization activity relates to making the service product more tangible and concrete (Bebko, 2000; Reddy, Buskirk, \& Kaicker, 1993). Tangibilizing services can lower the customers' psychological distance to the experience due to lower levels of abstraction for expectation and consumption enjoyment (Wakslak, Trope, \& Liberman, 2007). In other words, key to customers' value perception are the tangible elements of an offering (Santos, 2002). Branding in this context means to enhance this tangibility by giving a service product a name, term, symbol, and/or design to make it externally identifiable and distinctively perceived by customers.

As such, tangibilization of a service product and its value proposition in a narrow sense refers to physical tangibility (the service product becomes touchable and visible), which in the end, helps to make the service product mentally tangibility (it can be more easily understood and recognized). Such physical tangibilization can be achieved by developing brand names, logos, physical materials, visualizations of key stages of the service processes, fact sheets, manuals, floor plans, orientation videos, and photographic material (Hyötyläinen \& Möller, 2007; Jaakkola, 2011; Lehtonen, Järvi, \& Tuominen, 2015). Other examples are linguistic (e.g., a 
telling brand name such as LUX*'s Cinema Paradiso) and visual cues for a service (e.g., product replicas in the shop window of a Sushi bar).

Yet, in a wider sense, branding is predominantly about making the service mentally more tangible, and creating physical tangibility helps to serve this purpose. In other words, a service product depicted with names and logos as well as the visualization of key processes and deliverables makes the service more concrete in the customers' minds, and helps them to conceive what the service is about, affecting perceived risk and consumption decisions.

Finally, branding a service product requires a multi-level perspective. Berry (2000) observed that for "services, the company is the primary brand" (p. 128). Productizing services requires firms to depart from this practice and develop brands at various levels (e.g., branding the firm, individual service products, solutions, bundles, and even specific experiences and customer service). As all these brands have to build on and support each other, firms need to develop a brand architecture. Our LUX* case study illustrates such an architecture, which is comprised of the overall company brand (i.e., LUX*) with its positioning and value position (i.e., "help people celebrate life"), brands for individual resorts (e.g., its LUX* Belle Mare resort in Mauritius), product brands targeted at specific customer needs (e.g., its wedding product called "Wedding Delight Package"), and its many branded experiences (e.g., Cinema Paradiso).

\subsection{Pricing}

The price of productized services should be stated upfront, clearly communicated, and committed. The art and science of pricing is discussed in great depth elsewhere (e.g., Monroe, 2002). Service-specific issues that relate closely to productization are revenue management (i.e., dynamic pricing of capacity-constrained services) and tiering of service that develop service 
products for target segments with different price sensitivities and needs. Rate fences specify clearly what a particular offer entails (e.g., physical rate fences such as different seat categories in a theater, or non-physical rate fences such as 'happy hour' offers or 'saver tickets' of airlines that come with restrictions in exchange for a lower price; Kimes \& Wirtz, 2015). Tiering of service is used to specify the performance levels attached to a service product (e.g., on-site versus telephone IT support service).

\subsection{Supporting organizational resources and infrastructure}

As illustrated in Figure 1, the core service product and its value proposition, as well as the processes needed for delivering it, rely on a set of organizational resources (c.f. Edvardsson \& Olsson, 1996). Productization of services typically requires developing new supportive resources that enable delivering the clearly specified content of the service through unified and systematized processes. Such supportive resources can entail methods, operational models, tools, and materials, such as document templates, process charts, databases, and analysis methods (Harkonen, Tolonen, \& Haapasalo, 2017; Jaakkola, 2011). Tuominen and Martinsuo (2019) call these supportive materials 'codified process templates' comprised of written rules, service models, process blueprints, and tools. Such templates function as the backbone of systematic, unified processes and offerings.

The nature of the supportive materials depends on the service. For some services, materials facilitating the adoption of unified service provision - for example service scripts and service manuals - are key for ensuring a consistent customer experience across service encounters. For more idiosyncratic services, such as professional services, productization activities often focus on codifying tacit knowledge across the company, thus making it available 
in an explicit form (Valtakoski \& Järvi, 2016). More systematic and unified work processes is a means of capturing and accumulating the information and experience that is gained through individual customer projects (Jaakkola, 2011). For example, in a professional service firm, such as law firms, service productization promotes the reuse of knowledge from previous projects, which facilitates the development of collective understanding of the services and improves the efficiency of projects (Valtakoski \& Järvi, 2016). Standardization of service contents and processes also facilitates further knowledge codification and accumulation since it supports the sharing of knowledge, learning, and developing an aggregate understanding on the effectiveness of particular approaches (Lehtonen, Järvi, \& Tuominen, 2015; Jaakkola, 2011).

\section{Implications, conclusions and further research}

Developing well-defined service products translates abstract, generic and often fuzzy services into concrete offerings. Having such productized services has important implications for key stakeholders, which we discuss next together with our conclusions.

\subsection{Implications for service organizations}

We consider the benefits for marketing, sales and distribution as a key implication of service productization. We proffer that productization helps to ensure that service products not only are well-developed with well-articulated, documented and visualized features and descriptions, a brand, a logo, and a defined pricing structure, but that they offer a clear value proposition with a defined way of buying. All these elements can be used in an effective manner in a firm's external communications, including its marketing collateral, website, social media, and personal selling. As a consequence, customers can better understand what the service entails 
and what its unique features are, which makes selecting and buying of services easier and lowers the customers' risk perceptions.

Yet, service productization does not only improve external marketing with customers, but service branding, as a major component of service productization, also serves internal marketing purposes. Specifically, service branding enables and supports the service organization and its employees in making adequate promises about the service (Brodie, 2009). For salespeople in particular, service productization can serve as an antidote to the increasingly complex work environment and job demands. A meta-analytical study of variables that predict sales performance found that sales-related knowledge plays a key role for success (Verbeke, Dietz, \& Verwaal, 2010). Sales people need clear structures and processes in order to be able to manage complexity that comes from customer interactions (Schmitz \& Ganesan, 2014) and to counteract role stressors that negatively affect their performance. Sales processes are made more efficient if pre-defined processes and methods are adopted (Jaakkola, 2011). Put simply, service productization helps salespeople to better understand what they sell, thus increasing their performance. Similarly, frontline employees can better understand productized services, explain them more effectively (e.g., almost every Starbucks employee can describe key products with enthusiasm and confidence), and deliver them consistently and system-wide at high quality.

Finally, highly productized services can be more easily scaled up. Scaling is a key success factor for services (Di Pietro et al., 2018), both within the firm (e.g., when seeking to expand business activities and leverage on economies of scale through replicating the service product at a larger scale), and across distribution systems such as global electronic distribution networks, websites, apps, booking aggregators, review websites in the hotel industry, and 
franchise systems (e.g., in fast food). These systems need to draw on concrete service products to leverage sales, which can be achieved by productization.

\subsection{Implications for customers}

Previous research has found that customers frequently lack a "clear understanding of what they need and what the company could offer them" (Jaakkola, 2011, p. 224). Productizing services has profound positive effects on the customer experience at every stage of the customer journey (Harkonen, Haapasalo, \& Hanninen, 2015). In the following, we describe these benefits, using the three key stages of the service process - the pre-purchase, service encounter, and postencounter stage.

Pre-purchase stage. For services, the pre-purchase stage introduces challenges not found when purchasing physical products (Fisk, 1981). Consumer expertise and knowledge are particularly important because there is a heightened perceived risk in purchasing services as opposed to physical products (Laroche et. al., 2004). Perceptions of risk increase with an increasing variability of a service offering as consumers do not know what to expect.

Here, a major benefit of service productization is that it can reduce customers ' risk perceptions (Ding \& Keh, 2016; Laroche et al., 2004; Murray \& Schlacter, 1990). This is because highly productized services are largely standardized. Standardization allows a service to be defined and described to customers (Harkonen, Tolonen, \& Haapasalo, 2017), thereby providing them with a clear picture of what exactly they can expect to receive for their money, time, and effort. At the same time, standardization minimizes variability whereby one and the same service can be offered many times with few variations (Djellal, Gallouj, \& Miles, 2013). Hence, customers are assured to receive consistent quality. 
Another benefit of service productization at the pre-purchase stage is that customers can better gauge the value of the service product. Specifically, customers can better understand what the service comprises (e.g., what are its key elements), how it is created (e.g., what are the main steps of the process and experience, and what will happen when), and what value they will receive (e.g. what is delivered, what is the experience and outcome, why it works, and what is so special about it). Comprehensibility of a product and its pricing structure has even been shown to increase consumers' willingness to pay (Jaakkola, 2011). Accordingly, service productization has the potential to pay off through increased margins.

Service encounter stage. The service encounter stage is characterized by the provision of a service to customers via one, or a series of, interactions with the firm. During this stage, both parties co-create the service and interact to accomplish mutual objectives. These interactions are governed by service scripts and roles, which together dictate appropriate service sequences, dialogue, and behaviors on the part of both customers and employees (Miao, Mattila, \& Mount, 2011). Service productization systematizes this co-creation process and creates replicable routines (Harkonen, Tolonen, \& Haapasalo, 2017) that enhance the understanding of service scripts and roles, and thus improves the co-creation process as a functional benefit. Smoothing the co-creation process may also have the positive side effect that routines are comfortable to both customers and employees, which may represent a social value as smooth interactions can improve relationships.

Another benefit of service productization and its higher level of standardization is that it allows for the same service process to be repeated many times with little variation (Djellal, Gallouj, \& Miles, 2013) and thereby reduces the risk of service failure and related negative emotions such as frustration, anger, and helplessness (Gelbrich, 2010). Standardization mitigates 
this risk by ensuring that the service delivery process can consistently meet customer expectations.

Finally, productization reduces complexity (Djellal, Gallouj, \& Miles, 2013). This increases customers' cognitive capacity, which in turn increases enjoyment of the service experience (Kumar et al., 2019) and, as discussed next, subsequent satisfaction (Mikolon, Kolberg, Haumann, \& Wieseke, 2015).

Post-encounter stage. As shown in the previous sections, service productization should lead to a smoother, less complex, less failure-prone and more enjoyable service encounter, and therefore increase customer satisfaction. Furthermore, there is convincing evidence that enhanced tangibility, as is achieved by productization, increases customers' perception of service quality (Parasuraman, Zeithaml, \& Berry, 1988) which, again, increases customer satisfaction (Bitner, 1992). Furthermore, branding also makes a service product more tangible, and along with upfront pricing, helps set realistic and accurate expectations of what exactly the customer will receive. Following the expectancy-disconfirmation model, customer's confirmed expectations regarding the service are key to their satisfaction (Oliver, 1980). Combined, these outcomes have the potential to increase repatronage and referral behaviors.

\subsection{Potential drawbacks of service productization}

We acknowledge that service productization may not be suitable for all players in an industry. Potential downsides of well-developed service products may include a loss of creativity. For example, McKinsey positions itself on crafting cutting-edge, creative, and individualized solutions for their clients that may lead to breakthrough innovative strategies. That is, McKinsey differentiates itself sharply from firms such as Accenture that sell more well- 
developed solutions and McKinsey might argue that these "cookie-cutter-type products" are unlikely to be a game-changer for their clients. It has even been suggested in the context of professional services that too much specification can become "coercive, lowering employees' motivation and value-creation capabilities" (Tuominen \& Martinsuo, 2019, p. 51).

Productization may also reduce perceptions of authenticity, which can be important in contexts such as art and cultural experiences, and may introduce perceptions of "commodification" (Fritze et al., 2020). In a similar vein, productization may reduce feelings of individualization, surprise, and spontaneity. These could be important in settings where customers do not want to have well-defined service products such as in adventure tours and elite cultural experiences, when customers prefer to have authentic or bespoke experiences that are highly personalized and tailored exactly to their individual needs and wants (c.f., Wirtz, Holmqvist, \& Fritze, 2020).

\subsection{Further research}

Our article synthesized the current productization literature, and enriched the extant definitions of productization and highly productized services by augmenting it with the concepts of branding and pricing. As this article is conceptual, there is a plethora of further research opportunities. First, we proposed that productized services are positioned on a continuum ranging from a low to a high degree of productization. It would be of interest to understand how the three dimensions of specification, branding, and pricing translate into various degrees of productization, and how they should be applied. For example, what is needed to make a product highly productized in the eyes of consumers so that they mentally can processes it akin to a tangible good? Are there circumstances where focusing only on some dimensions is beneficial? 
Second, the literature on cost-effective service excellence uses a number of operations management approaches that help to 'industrialize' services to reduce costs while increasing service quality (Wirtz \& Zeithaml, 2018). The approaches and tools in this literature have not been examined in the context of service productization but seem promising. For example, potentially suitable approaches and tools include buffering the front-office from the back-office and industrializing the back-office, shifting activities from the expensive front-office to the industrialized back-office, using plant-within-plant approaches, reducing convergence and complexity of processes, and deploying systems, self-service technologies, service robots and intelligent automation (c.f., Bornet, Barkin, \& Wirtz, 2021; Wirtz et al., 2018) to industrialize the front-office. Future research should integrate operations management, intelligent automation, and service productization approaches.

Third, the current service innovation literature has embraced the specification dimension of service productization, less so branding and pricing. We believe that explicitly exploring how the latter two can be integrated better in the productization literature are needed. For example, the concepts of brand architectures and rate fences can both help to define service products.

Fourth, we hope that our thinking on well-defined service products will resonate with literature on new service development, service design, and design thinking. Recent papers emphasize the need to connect new service development more clearly to value cocreation (Yu \& Sangiorgi, 2019; Helkkula, Kowalkowski, \& Tronvoll, 2018). It would be interesting to explore how service productization and well-defined service products can support this endeavor. Specifically, empirical studies are needed on if, how, and why service productization translates into more intense value cocreation. 
Finally, recent research offers diverse findings regarding the perceived value of digital products and services compared to physical products (e.g., Atasoy \& Morewedge, 2018; Fritze et al., 2020). The general notion is that physical products are more concrete and thus more valued than non-physical products. However, this might change if non-physical products are made more concrete by employing service productization. We thus wonder how well-defined service products can deliver at levels of concreteness and mental tangibility mimicking those of physical products, and thus might mitigate consumers' preferences for physical over non-physical products. Combined with the well-document effect that consumers derive greater happiness from purchasing experiences compared to material possessions (Weingarten \& Goodman, 2021) such research could help nudge customers towards sharing economy platforms and other services that replace the more resource-intensive ownership of physical goods.

In closing, we are convinced that the topic of crafting well-defined service products and service productization are important and deserve more attention. We hope that our article will inspire further studies in this field. 


\section{References}

Aaker, D.A (1991). Managing Brand Equity: Capitalizing on the Value of a Brand Name. New York: Free Press. Harvard (18th ed.).

Aaker, D.A. (1996). Measuring brand equity across products and markets. California Management Review, 38(3), 102-120.

AMA. (2021). 4 Ps of marketing. Retrieved from: https://www.ama.org/the-definition-ofmarketing-what-is-marketing. Accessed August 3, 2021

Aapaoja, A., Kujala, J., \& Pesonen, L. T. (2012). Productization of university services. International Journal of Synergy and Research, 1(1), 89-106.

An, D. (2014). Tangibilizing services through visual tangible cues in corporate web sites: A sixcountry cross-cultural analysis. Journal of Services Marketing, 28(7), 566579.https://doi.org/10.1108/JSM-04-2013-0097.

Andreini, D., Salo, J., Wendelin, R., Pezzotta, G., \& Gaiardelli, P. (2015). From a servicedominant logic to a good-dominant logic. IMP Journal, 9(3), 250-266. https://doi.org/10.1108/imp-07-2015-0034.

Atasoy, O., \& Morewedge, C. K. (2018). Digital goods are valued less than physical goods. Journal of Consumer Research, 44(6), 1343-1357. https://doi.org/10.1093/jcr/ucx102.

Avlonitis, G.J., Indounas, K.A., \& Gounaris, S.P. (2005). Pricing objectives over the service life cycle: some empirical evidence. European Journal of Marketing, 39(5/6), 696-714. https://doi.org/10.1108/03090560510590773

Bebko, C. (2000). Service intangibility and its impact on consumer expectations of service quality. Journal of Services Marketing, 14(1), 9-26. https://doi.org/10.1108/08876040010309185.

Berry, L.L. (2000). Cultivating service brand equity. Journal of the Academy of Marketing Science, 28, 128-137. https://doi.org/10.1177/0092070300281012 
Bitner, M.J. (1992). Servicescapes: The impact of physical surroundings on customers and employees. Journal of Marketing, 56(2), 57-71. Doi:10.1177/002224299205600205

Bitner, M. J., Ostrom, A. L., \& Morgan, F. N. (2008). Service blueprinting: A practical technique for service innovation. California Management Review, 50(3), 66-94. https://doi.org/10.2307/41166446.

Bornet, P., Barkin I., \& Wirtz J. (2021). Intelligent Automation: Welcome to the World of Hyperautomation. World Scientific Books.

Brodie, R.J. (2009). From goods to service branding: An integrative perspective. Marketing Theory. 9(1), 107-111. doi:10.1177/1470593108100064.

Clemes, M., Mollenkopf, D., \& Burn, D. (2000). An investigation of marketing problems across service typologies. Journal of Services Marketing, 14(6/7), 573-594. https://doi.org/10.1108/08876040010352754.

Ding, Y., \& Keh, H. T. (2016). A re-examination of service standardization versus customization from the consumer's perspective. Journal of Services Marketing, 30(1), 16-28. https://doi.org/10.1108/JSM-02-2015-0088.

Di Pietro, L., Edvardsson, B., Reynoso, J., Renzi, M. F., Toni, M., \& Mugion, R.G. (2018). A scaling up framework for innovative service ecosystems: lessons from Eataly and KidZania. Journal of Service Management, 29(1), 146-175. https://doi.org/10.1108/JOSM02-2017-0054.

Djellal, F., Gallouj, F., \& Miles, I. (2013). Two decades of research on innovation in services: Which place for public services? Structural Change and Economic Dynamics, 27, 98-117. https://doi.org/10.1016/j.strueco.2013.06.005.

Edvardsson, B., \& Olsson, J. (1996). Key concepts for new service development. Service Industries Journal, 16(2), 140-164. https://doi.org/10.1080/02642069600000019.

Eissens-Van der Laan, M., Broekhuis, M., van Offenbeek, M., \& Ahaus, K. (2016). Service decomposition: a conceptual analysis of modularizing services. International Journal of 
Operations \& Production Management, 36(3), 308-331. https://doi.org/10.1108/IJOPM06-2015-0370

Elia, V., Gnoni, M. G., \& Tornese, F. (2019). Exploring the benefits of productization in the utilities sector. Sustainability, 11(20), 5864. https://doi.org/10.3390/su11205864.

Fisk, R. P. (1981, January). Toward a consumption/evaluation process model for services. Proceedings of the American Marketing Association Conference, Florida.

Fließ, S., \& Kleinaltenkamp, M. (2004). Blueprinting the service company - Managing service processes efficiently. Journal of Business Research, 57(4), 392-404. https://doi.org/10.1016/S0148-2963(02)00273-4.

Fritze, M. P., Marchand, A., Eisingerich, A. B., \& Benkenstein, M. (2020). Access-based services as substitutes for material possessions: the role of psychological ownership. Journal of Service Research, 23(3), 368-385. https://doi.org/10.1177/1094670520907691.

Gelbrich, K. (2010). Anger, frustration, and helplessness after service failure. Coping strategies and effective informational support. Journal of the Academy of Marketing Science, 38(5), 567-585. https://doi.org/10.1007/s11747-009-0169-6.

Goldstein, S. M., Johnston, R., Duffy, J. A., \& Rao, J. (2002). The service concept: The missing link in service design research? Journal of Operations Management, 20(2), 121-134. https://doi.org/10.1016/S0272-6963(01)00090-0.

Gremyr, I., Valtakoski, A., \& Witell, L. (2019). Two routes of service modularization: advancing standardization and customization. Journal of Services Marketing, 33(1), 73-87. https://doi.org/10.1108/JSM-10-2018-0285

Grönroos, C. (2020). Viewpoint: service marketing research priorities. Journal of Services Marketing, 34(3), 291-298. https://doi.org/10.1108/JSM-08-2019-0306.

Harkonen, J., Haapasalo, H., \& Hanninen, K. (2015). Productisation: A review and research agenda. International Journal of Production Economics, 164, 6582.https://doi.org/10.1016/j.ijpe.2015.02.024. 
Harkonen, J., Tolonen, A., \& Haapasalo, H. (2017). Service productisation: systematising and defining an offering. Journal of Service Management, 28(5), 936.971. https://doi.org/10.1108/JOSM-09-2016-0263.

Helkkula, A., Kowalkowski, C., \& Tronvoll, B. (2018). Archetypes of service innovation: implications for value creation. Journal of Service Research, 21(3), 284-301. https://doi.org/10.1177/1094670517746776.

Hyötyläinen, M., \& Möller, K. (2007). Service packaging: Key to successful provisioning of ICT business solutions. Journal of Services Marketing, 21(5), 304-312. https://doi.org/10.1108/08876040710773615.

Jaakkola, E. (2011). Unraveling the practices of "productization" in professional service firms. Scandinavian Journal of Management, 27(2), 221-230. https://doi.org/10.1016/j.scaman.2011.03.001.

Jaakkola, E. (2020). Designing conceptual articles: Four approaches. AMS Review, 10, 18-26.

Jaakkola, E., \& Hallin, A. (2018). Organizational structures for new service development. Journal of Product Innovation Management, 35(2), 280-297. https://doi.org/10.1111/jpim.12399.

Kalyanaram, G., \& Krishnan, V. (1997). Deliberate product definition: Customizing the product definition process. Journal of Marketing Research, 34(2), 276-285. https://doi.org/10.1177/002224379703400207.

Kimes, S. E., \& Wirtz, J. (2015). Revenue management: Advanced strategies and tools to enhance firm profitability. Foundations and Trends in Marketing, 8(1), 1-68. http://dx.doi.org/10.1561/1700000037.

Kotler, P., \& Armstrong, G. (2021). Principles of Marketing (17th edition). Pearson.

Kumar, V., Rajan, B., Gupta, S., \& Pozza, I. D. (2019). Customer engagement in service. Journal of the Academy of Marketing Science, 47(1), 138-160. https://doi.org/10.1007/s11747-017-0565-2. 
Laroche, M., McDougall, G. H. G., Bergeron, J., \& Yang, Z. (2004). Exploring how intangibility affects perceived risk. Journal of Service Research, 6(4), 373-389. https://doi.org/10.1177/1094670503262955.

Lehtonen, M. H., Järvi, K., \& Tuominen, T. (2015). Reflexivity in the "productisation" of services. International Journal of Work Innovation, 1(2), 161-184. https://doi.org/10.1504/IJWI.2015.071188.

Lovelock, C., \& Gummesson, E. (2004). Whither services marketing? Journal of Service Research, 7(1), 20-41. https://doi.org/10.1177/1094670504266131.

Ma, J., \& Kremer, G. E. O. (2016). A systematic literature review of modular product design (MPD) from the perspective of sustainability. The International Journal of Advanced Manufacturing Technology, 86(5), 1509-1539. https://doi.org/10.1007/s00170-015-8290-9.

McDougall, G.H.G., \& Snetsinger, D.W. (1990). The intangibility of services: measurement and competitive perspectives. Journal of Services Marketing, 4(4), 27-40. https://doi.org/10.1108/EUM0000000002523

Miao, L., Mattila, A. S., \& Mount, D. (2011). Other consumers in service encounters: A script theoretical perspective. International Journal of Hospitality Management, 30(4), 933-941. https://doi.org/10.1016/j.ijhm.2011.01.012.

Mikolon, S., Kolberg, A., Haumann, T., \& Wieseke, J. (2015). The complex role of complexity: How service providers can mitigate negative effects of perceived service complexity when selling professional services. Journal of Service Research, 18(4), 513-528. https://doi.org/10.1177/1094670514568778.

Monroe, K. (2002). Pricing: Making Profitable Decisions. $3^{\text {rd }}$ edition. McGraw-Hill/Irwin.

Murray, K. B., \& Schlacter, J. L. (1990). The impact of services versus goods on consumers' assessment of perceived risk and variability. Journal of the Academy of Marketing Science, 18(1), 51-65. https://doi.org/10.1007/BF02729762. 
Oliver, R. L. (1980). A cognitive model of the antecedents and consequences of satisfaction decisions. Journal of Marketing Research, 17(4), 460. https://doi.org/10.2307/3150499.

Padgett, D., \& Allen, D. (1997). Communicating experiences: a narrative approach to creating service brand image. Journal of Advertising, 26(4), 49-62, DOI:

$10.1080 / 00913367.1997 .10673535$

Pil, F. K., \& Cohen, S. K. (2006). Modularity: Implications for imitation, innovation, and sustained advantage. Academy of Management Review, 31(4), 995-1011. https://doi.org/10.5465/AMR.2006.22528166.

Rahikka, E., Ulkuniemi, P., \& Pekkarinen, S. (2011). Developing the value perception of the business customer through service modularity. Journal of Business and Industrial Marketing, 26(5), 357-367. https://doi.org/10.1108/08858621111144415.

Reddy, A. C., Buskirk, B. D., \& Kaicker, A. (1993). Tangibilizing the intangibles: Some strategies for services marketing. Journal of Services Marketing, 7(3), 13-17. https://doi.org/10.1108/08876049310044510.

Salunke, S., Weerawardena, J., \& McColl-Kennedy, J. R. (2013). Competing through service innovation: The role of bricolage and entrepreneurship in project-oriented firms. Journal of Business Research, 66(8), 1085-1097. https://doi.org/10.1016/j.jbusres.2012.03.005.

Santos, J. (2002). From intangibility to tangibility on service quality perceptions: a comparison study between consumers and service providers in four service industries. Managing Service Quality, 12(5), 292-302. https://doi.org/10.1108/09604520210442083.

Schmitz, C., \& Ganesan, S. (2014). Managing customer and organizational complexity in sales organizations. Journal of Marketing, 78(6), 59-77. https://doi.org/10.1509/jm.12.0296.

Shostack, G. L. (1977). Breaking free from product marketing. Journal of Marketing, 41(2), 73 80. https://doi.org/10.2307/1250637. 
Tuominen, T., \& Martinsuo, M. (2019). Employees' agency in the formalisation of knowledgeintensive business service processes: A cross-case comparison. Journal of Service Theory and Practice, 29(1), 45-70. https://doi.org/10.1108/JSTP-10-2017-0184.

Valminen, K., \& Toivonen, M. (2012). Seeking efficiency through productisation: A case study of small KIBS participating in a productisation project. Service Industries Journal, 32(2), 273-289. https://doi.org/10.1080/02642069.2010.531260.

Valtakoski, A., \& Järvi, K. (2016). Productization of knowledge-intensive services. Journal of Service Management, 27(3), 360-390. https://doi.org/10.1108/josm-01-2015-0004.

Verbeke, W., Dietz, B., \& Verwaal, E. (2010). Drivers of sales performance: A contemporary meta-analysis. Have salespeople become knowledge brokers? Journal of the Academy of Marketing Science, 38(3), 407-428. https://doi.org/10.1007/s11747-010-0211-8.

Verma, R. (2000). An empirical analysis of management challenges in service factories, service shops, mass services and professional services. International Journal of Service Industry Management, 11(1), 8-25. https://doi.org/10.1108/09564230010276924.

Wakslak, C., Trope, Y., \& Liberman, N. (2007). Construal levels and psychological distance: Effects on representation, prediction, evaluation, and behavior. Journal of Consumer Psychology, 17(2), 83-95. https://doi.org/10.1016/S1057-7408(07)70013-X.

Weingarten, E., \& Goodman, J. K. (2021). Re-examining the experiential advantage in consumption: A meta-analysis and review. Journal of Consumer Research, 47(6), 855-877. https://doi.org/10.1093/jcr/ucaa047.

Wirtz, J. (2021). Viewpoint: Service products, development of service knowledge and our community's target audience. Journal of Services Marketing, 35(3), 265-270. https://doi.org/10.1108/JSM-03-2020-0086.

Wirtz, J., \& Kaufman, R. (2016). Revolutionizing customer service, Harvard Business Review, 94(4), 26-27. 
Wirtz, J., \& Lovelock, C. (2016), Services Marketing: People, Technology, Strategy (8th ed.). New Jersey: World Scientific.

Wirtz, J., \& Zeithaml, V. (2018). Cost-effective service excellence. Journal of the Academy of Marketing Science, 46(1), 59-80.

Wirtz, J., Holmqvist, J. \& Fritze, M.P. (2020). Luxury services. Journal of Service Management. 31(4), 665-691

Wirtz, J., Patterson, P.G., Kunz, W.H., Gruber, T., Lu, V.N., Paluch, S., \& Martins, A. (2018). Brave new world: service robots in the frontline. Journal of Service Management, 29(5), 907-931.

Yu, E., \& Sangiorgi, D. (2018). Service design as an approach to implement the value cocreation perspective in new service development. Journal of Service Research, 21(1), 40-58. https://doi.org/10.1177/1094670517709356.

Zeithaml, V. A., Parasuraman, A., \& Berry, L. L. (1985). Problems and strategies in services marketing. Journal of Marketing, 49(2), 33-46. https://doi.org/10.1177/002224298504900203. 